\title{
Centers for Disease Control "increased-risk" organ donor: Not so risky?
}

\author{
Francis D. Pagani, MD, PhD
}

\author{
From the Department of Cardiac Surgery, University of Michigan, Ann Arbor, Mich. \\ Disclosures: Author has nothing to disclose with regard to commercial support. \\ Received for publication Aug 19, 2018; accepted for publication Aug 21, 2018; available ahead of print Sept 20, \\ 2018. \\ Address for reprints: Francis D. Pagani, MD, PhD, Department of Cardiac Surgery, 5161 Cardiovascular Center, \\ SPC 5864, University of Michigan, 1500 East Medical Center Drive, Ann Arbor, MI 48109 (E-mail: fpagani@ \\ umich.edu). \\ J Thorac Cardiovasc Surg 2019;157:613-4 \\ $0022-5223 / \$ 36.00$ \\ Copyright (C) 2018 by The American Association for Thoracic Surgery \\ https://doi.org/10.1016/j.jtcvs.2018.08.039
}

Guidelines from the Centers for Disease Control and Prevention (CDC) and Public Health Service categorize organ donors as "increased risk" for disease transmission if donors meet certain criteria thought to increase the risk of undetected human immunodeficiency virus (HIV), hepatitis B virus infection, or hepatitis $\mathrm{C}$ virus (HCV) infection. ${ }^{1,2}$ These guidelines were developed to improve the safety of organ transplantation by reducing HIV, hepatitis B virus, and HCV transmission without adversely affecting organ availability. $^{2,3}$ This balance of goals is critical given the significant shortage of donor organs, particularly for heart transplantation. ${ }^{4}$ Since the implementation of recent guidelines, the number of deceased donors classified as CDC "increased risk" has increased to approximately 1 in 5 donors nationally. ${ }^{2,5}$ Although the risk that a CDC high-risk donor is infected with HIV or HCV is increased compared with a non-high-risk donor, the absolute risk is low, particularly with new testing methodology that reduces the window period and identifies the presence of virus earlier

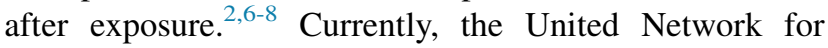
Organ Sharing mandates that centers obtain special informed consent from patients when a CDC high-risk organ is considered for transplantation. ${ }^{9}$ The potential stigma of accepting an "increased-risk" donor and lack of education of physicians and patients regarding the actual risk have led to increased rates of discard of donors from the CDC high-risk donor pool. ${ }^{10-12}$ However, data from single-center studies have suggested the use of CDC highrisk donors does not influence heart transplant survival. ${ }^{13}$

In this issue of the Journal, Shudo and colleagues ${ }^{14}$ investigated the impact on the use of CDC high-risk donors on heart transplant outcomes from the United Network for Organ Sharing database. By using propensity matching, the investigators identified a matched cohort consisting of 6740 CDC high-risk and non-high-risk donors. In a Cox proportional hazards model analysis, the investigators observed that the use of CDC high-risk donors did not adversely influence transplant survival (hazard ratio of

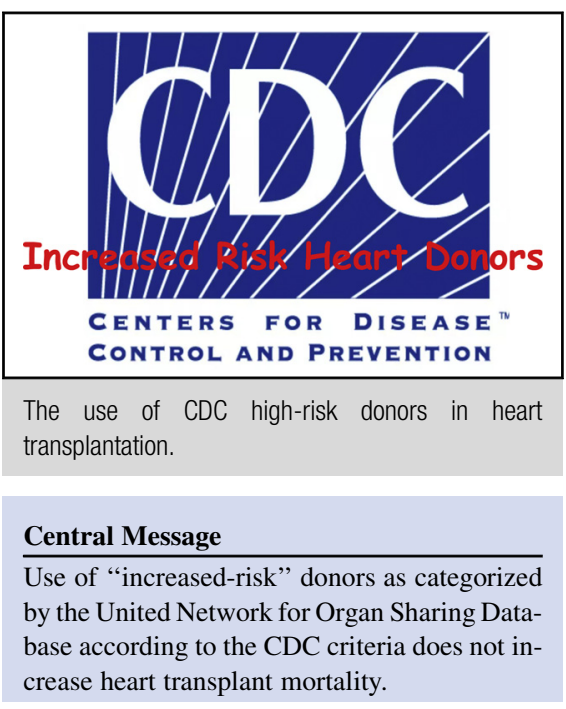

See Article page 603

CDC high-risk group vs non-CDC high-risk group, 0.97 ; $95 \%$ confidence interval, $0.87-1.08 ; P=.57)$. The investigators did observe a higher rate of acute myocardial rejection episodes during hospital stays in the CDC high-risk group, whereas post-transplant pacemaker placements were performed less frequently in the CDC high-risk group.

Although the study by Shudo and colleagues ${ }^{14}$ lacks detailed information on rates of seroconversion, outcomes for patients who have seroconverted, and differences in regional use of high-risk donors, the data from this study are reassuring and strongly support the strategy of using the CDC high-risk donor pool for heart transplantation. Given the recent opioid epidemic and the increasing number of donors who are meeting CDC high-risk donor criteria, these data become increasing relevant. ${ }^{15}$ As physicians, we have an obligation to educate our patients on the balance of risk associated with use of the CDC high-risk donor pool. The CDC high-risk donor should not represent a barrier to successful heart transplantation.

\section{References}

1. Rodgers MSR, Lawton KE, Moseley RR. Guidelines for preventing transmission of human immunodeficiency virus through transplantation of human tissue and organs. MMWR Recomm Rep. 1994;43(RR-8):1-18.

2. Understanding the risk of transmission of HIV, hepatitis B, and hepatitis C from U.S. PHS increased risk donors. Available at: https://optn.transplant.hrsa.gov/ media/2270/dtac_guidance_risks_201706.pdf. Accessed August 19, 2018.

3. Seem DL, Lee I, Umscheid CA, Kuehnert MJ. PHS guideline for reducing human immunodeficiency virus, hepatitis B virus, and hepatitis C virus transmission through organ transplantation. Public Health Rep. 2013;128:247-343. 
4. Cowger JA. Addressing the growing U.S. donor heart shortage. J Am Coll Cardiol. 2017;69:1715-7.

5. Kucirka LM, Bowring MG, Massie AB, Luo X, Nicholas LH, Segev DL, et al. Landscape of deceased donors labeled increased risk for disease transmission under new guidelines. Am J Transplant. 2015;15:3215-23.

6. Kucirka LM, Sarathy H, Govindan P, Wolf JH, Ellison TA, Hart LJ, et al. Risk of window period HIV infection in high infectious risk donors: systematic review and meta-analysis. Am J Transplant. 2011;11:1176-87.

7. Kucirka LM, Sarathy H, Govindan P, Wolf JH, Ellison TA, Hart LJ, et al. Risk of window period hepatitis-C infection in high infectious risk donors: systematic review and meta-analysis. Am J Transplant. 2011;11:1188-200.

8. Fischer SA, Avery RK. Screening of donor and recipient prior to solid organ transplantation. Am J Transplant. 2009;9:S7-18.

9. Guidance on explaining risk related to use of U.S. PHS increased risk donor organs when considering organ offers. Available at: https://optn.transplant.hrsa. gov/media/2116/guidance_increased_risk_organ_offers_20170327.pdf. Accessed August 19, 2018
10. Ros RL, Kucirka LM, Govindan P, Sarathy H, Montgomery RA, Segev DL. Patient attitudes toward CDC high infectious risk donor kidney transplantation: inferences from focus groups. Clin Transplant. 2012;26:247-53.

11. Volk ML, Wilk AR, Wolfe C, Kaul DR. The "PHS Increased Risk" label is associated with nonutilization of hundreds of organs per year. Transplantation. 2017; 101:1666-9.

12. Duan KI, Englesbe MJ, Volk ML. Centers for Disease Control 'high-risk' donors and kidney utilization. Am J Transplant. 2010;10:416-20.

13. Gaffey AC, Doll SL, Thomasson AM, Venkataraman C, Chen CW, Goldberg LR, et al. Transplantation of "high-risk" donor hearts: Implications for infection. J Thorac Cardiovasc Surg. 2016;152:213-20.

14. Shudo Y, Cohen JE, Lingala B, He H, Zhu Y, Woo YJ. Impact of "increased-risk" donor hearts on transplant outcomes: a propensity matched analysis. J Thorac Cardiovasc Surg. 2019;157:603-10.

15. Goldberg DS, Blumberg E, McCauley M, Abt P, Levine M. Improving organ utilization to help overcome the tragedies of the opioid epidemic. Am J Transplant. 2016;16:2836-41. 